Theory and Research in Education 2019, Vol. 17(2) 165-180

(C) The Author(s) 2019

Article reuse guidelines: sagepub.com/journals-permissions DOI: I0.1 I77/I4778785|9862544 journals.sagepub.com/home/tre

$\Theta$ SAGE

\title{
Mason Marshall
}

Pepperdine University, USA

\begin{abstract}
Despite how revered Socrates is among many educators nowadays, he can seem in the end to be a poor model for them, particularly because of how often he refutes his interlocutors and poses leading questions. As critics have noted, refuting people can turn them away from inquiry instead of drawing them in, and being too directive with them can squelch independent thought. I contend, though, that Socrates' practices are more defensible than they often look: although there are risks in refuting people and posing leading questions, Socrates has sensible ways of minimizing the risks, ways that are feasible even for teachers nowadays, and there are times when the risks are worth taking. I illustrate my point by discussing Plato's Meno.
\end{abstract}

\section{Keywords}

Education, Meno, Plato, Socrates

Though Socrates is widely regarded as a teacher par excellence, critics have asked, understandably, whether he is a good model for modern-day educators. On the one hand, he often subjects his interlocutors to withering refutations, and one danger in refuting someone who is new to inquiry is that, rather than motivating them to inquire further, it will only make them dispirited or angry, not to mention that they may be shamed or humiliated, as Socrates' interlocutors sometimes are. ${ }^{1}$ On the other hand, Socrates asks leading questions in many cases - bit by bit, he hands his interlocutors premade arguments that they simply assent to - and one danger in being so directive with other people is that it will divest them of the chance to think for themselves. ${ }^{2}$ For these reasons, especially, it can seem clear that Socrates' refutations and leading questions are ill-suited to their task. ${ }^{3}$

\section{Corresponding author:}

Mason Marshall, Religion and Philosophy Division, Pepperdine University, 24255 Pacific Coast Highway,

Malibu, CA 90263, USA.

Email: mason.marshall@pepperdine.edu 
I doubt that they are, though, and in the following I will explain why. I will not try to show that Socrates' approach is always apt, but I will argue that there is reason to reconsider it, because Socrates is savvier than he can look: although there are risks in refuting people and posing leading questions, Socrates has sensible ways of minimizing the risks, ways that are feasible even for teachers nowadays, and there are times when the risks are worth taking. By 'teacher' I will mean simply anyone who tries to help students gain knowledge (even just by motivating them to inquire or by equipping them with useful intellectual skills), and by 'student' I will mean simply anyone who is a candidate for learning. But among the teachers I will have in mind are those who work in schools today.

To be thorough, I would need to examine a range of cases where Socrates interacts with other people. What is appropriate in one situation may not work in another, and one has to adapt one's methods to each new occasion, as Socrates himself acknowledges in Plato's Phaedrus $;{ }^{4}$ so one question to ask is how well he does this. Since I have limited space, though, I will focus simply on his approach in Plato's Meno. I choose the Meno for two reasons. First, among educators it is a focal point for discussion of Socrates, in part since it contains a famous episode, Socrates' demonstration with a slave-boy, that many have taken to be paradigmatic of Socratic teaching. Second, the Meno shows Socrates both in a destructive mode, in which he refutes Meno and leaves him emptyhanded, and later in a constructive mode where Socrates simply hands Meno positive conclusions.

In the following, I will start by summarizing the parts of the Meno that will be most important for my purposes. Then I will discuss the ways Socrates offsets the dangers that come with refuting his interlocutor and giving him premade arguments. Though in the process I will describe a strategy that I think is authentically Socratic, my main question will be not what Socrates' reasons are for doing what he does, but simply whether there are good reasons to do it. I also will ask not whether Plato endorses what Socrates does, but just whether we should find merit in it..$^{5}$ In arguing that we should, I will acknowledge that tactics like his are not failsafe: Socratic teachers cannot eliminate the risks altogether and, in fact, can minimize them only to a degree. But in closing, I will explain why I think the potential benefits can be worth the risks that remain.

\section{An overview of the Meno}

For ease of reference, we can divide the Meno into three main parts, which I will call the Refutative Phase (70a-81a), the Digressive Phase (81a-86e), and the Constructive Phase $(86 \mathrm{e}-100 \mathrm{c})$. The first shows Socrates in his refutative mode, the third is where he shifts to a constructive mode most overtly, and the second is a digression in between. Socrates' chief interlocutor in this dialogue is Meno, a young man from Thessaly who is staying with the wealthy Anytus while visiting Socrates' Athens. Throughout the conversation, it is fair to say, Socrates wants to draw Meno into a certain sort of inquiry. To engage in this kind of inquiry is to investigate certain abstract, non-empirical questions, such as ethical, metaphysical, and epistemological questions ${ }^{6}$ and to have certain traits of character, or some share of them, at least. It is to be invested not in your beliefs but in the process of examining and refining them, such that, first, you are open to changing your mind in light of the evidence your investigation uncovers; second, you seek out all the salient evidence 
that is relevant to the issues you consider; and third, you are at pains to evaluate the evidence correctly.

In the Refutative Phase, Meno claims, in effect, to know what virtue is and to know it in such a way that he can defend a definition adequately (71b ff.). But though he offers several of his favorite definitions he has heard, over and over he is unable to answer Socrates' objections to them. By the end of this Phase of the conversation, Socrates perhaps has not refuted those definitions, but he clearly has refuted Meno's claim to have the sort of knowledge he says he has. ${ }^{7}$

In the process of refuting Meno, Socrates takes a provocative, edgy, even combative tone, and his refutations are so aggravating to Meno that eventually Meno balks. First, he blames his difficulties on Socrates, accusing him of practicing sorcery (80b6). Meno says: 'I think you are bewitching and beguiling me, simply putting me under a spell

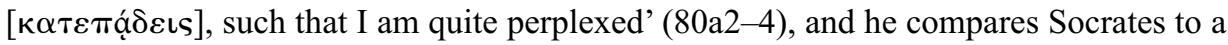
stingray that numbs everyone who goes near it. Soon thereafter, Meno also tries to derail the conversation, resorting to a maneuver that has come to be known as Meno's paradox (80d5-8). The gist of the argument in it is that inquiry is futile because we cannot seek what we know or do not know: if we know it already, we cannot seek it, and if we do not know it, we will not know what to seek.

In response, Socrates moves the dialogue into its Digressive Phase, gradually switching to a gentler, friendlier tone and offering Meno a version of the theory of recollection $(81 \mathrm{a}-\mathrm{d})$, as it is called. Socrates says he has gleaned it from wise poets such as Pindar and has heard it from priests and priestesses. According to them, he claims, every human soul undergoes reincarnation; buried within the soul is knowledge of all it has seen in previous lives and in the underworld; and inquiry can recollect this knowledge to the soul, such that inquiry is worthwhile after all. As proof of the theory of recollection, Socrates carries out a demonstration with Meno's slave-boy (82b-86b), who evidently does not understand geometry at first, but who arrives at certain truths about it when Socrates asks him a series of questions.

As the conversation then enters the Constructive Phase, Socrates offers Meno a range of additional positive theses regarding, in particular, the original question Meno poses in the dialogue, which is whether virtue is teachable. In the Constructive Phase, as in the Digressive Phase, Meno is persuaded (see, for example, 86b5, c3, 100b1); he changes from annoyed to enthusiastic and apparently starts to get a feel for inquiry, even saying a couple of times that there are certain things he wonders about $(\theta \alpha v \mu \alpha \dot{\zeta} \omega$ : $96 \mathrm{~d} 2,97 \mathrm{c} 11)$. Anytus, though, Meno's host, arrives near the start of this Phase to witness and take part in the conversation, and he is unhappy with much of what Socrates says. In fact, Anytus acts incensed and may be even angrier than he appears, since later, in Plato's Apology (23e), he is one of the accusers who bring Socrates to trial.

\section{Socrates' diversion in the Refutative Phase}

Part of what can seem most misguided about Socrates' refutations is the tone in which he delivers them: antagonism is antithetical to what many modern-day teachers aim for. So I want to start by noting that, in the Refutative Phase of the Meno, even Socrates' testiness serves a sensible purpose. 
First, let me be more precise than I was above. Generally, when it is clear that a student has been refuted, as it comes to be in Meno's case, there are three specific dangers that a Socratic teacher needs to guard against:

- Though the student will accept that they have been refuted, they will give up on inquiry. They will decide it is too difficult in the sense that they are not equipped to succeed at it or, perhaps, that no one is well enough equipped. ${ }^{8}$

- The student will accept that they have been refuted and will be enthralled with reasoning and other tools of inquiry, yet not as means of finding truth or knowledge but just as weapons for gaining power or prestige.

- Though it is clear that the student has been refuted - clear, in other words, that their claim has been shown to be false - the student will, through self-deception or wishful thinking, convince themselves that it has not been. ${ }^{9}$ They will decide that somehow, in a way they cannot identify, their interlocutor has outfoxed them with nothing more than a clever trick.

Plato himself points to these dangers - the first in the Meno (80d5-8), the second at one point in his Republic (539b2-8), and the third in his Euthyphro (11c9-d2) - and he does so with good reason. Anyone who has taught introductory courses in philosophy, for example, can attest that these dangers are often palpable.

Happily, the second danger is not very pressing in Meno's particular case: because of who Meno is, there is little chance that he will misuse the tools of inquiry to gain power or prestige. Though he is after power and prestige, he already has other tools for getting them, tools that he is enamored of and is set on using. Rather than outwitting people in dialectical exchanges, Meno likes to dazzle them with fancy speeches. I use the term 'speeches' (logoi) loosely. He does enjoy speaking before crowds, as he puts it (80b3), but he is anxious to perform well even in private conversation. What he hopes to do, in whatever venue, is impress people by giving 'bold and grand answer[s]' to interesting questions 'as experts are likely to do' $(70 \mathrm{~b} 6-\mathrm{c} 1)$. As a result, he is always on the hunt for exotic ideas that have appeal; Meno is someone who shops around for cool things to say. ${ }^{10}$ This is evident even in his opening question at the start of the dialogue: 'Can you tell me, Socrates, can virtue be taught?' (70a1-2). Whether virtue is teachable is a hot question in Meno's day, and Sophists, like pundits, each have their own answer prepared. Meno assumes that so does Socrates, and Meno wants to hear Socrates' answer so that Meno can make it his own if it seems marketable. In short, he approaches Socrates as if Socrates were Gorgias, a Sophist whom Meno has studied under. ${ }^{11}$ For Meno, a teacher is simply a source of useful speeches to appropriate (cf. 71d1-3, 73c78 ), and Meno is so preoccupied with his search for speeches that Socrates will only seem like a bad teacher. Meno won't want to imitate Socrates' refutations; he will only find them frustrating.

But although Socrates need not worry much about the second danger where Meno is concerned, Socrates does need to keep in mind the other two dangers. And importantly, he needs to guard against the first one, in particular. The first danger is more important to avoid, since it is better for students to despair of the teacher than to despair of inquiry itself. This is why, at least in one respect, Socrates does well to take a provocative tone 
in the Refutative Phase. His abrasiveness can be off-putting to teachers nowadays, but here it has a significant function. It invites Meno to think just that Socrates is a jerk, so that if Meno blames anything other than himself for his difficulties, it will only be Socrates he blames.

I should be clear about what my point is. What is notable in Socrates' approach is just that he orients Meno away from despairing of inquiry. Teachers nowadays need not be antagonistic; there are alternatives that serve the same purpose. For example, in a selfeffacing way a college teacher might act playfully pompous while delivering refutations, so that the natural assumption at first is that their only purpose is comedy: rather than being integral to inquiry or to whatever the students are there to learn, they are, at best, a diversion from it or, at worst, a waste of class time. Often, quite likely, it will be easy enough for students to make that assumption at first. There is something of Meno in all of us, probably, and certainly in many students in school, including the brightest and most earnest students. Many have inherited a certain image of education that has been slow to fade. At some level, understandably, even college students may think the job of a teacher is to fill them with speeches that impress people (admissions committees, for example, or potential employers) and that the rest is peripheral.

\section{Socrates' appeal in the Digressive Phase}

Socrates also needs to guard against the third danger: after annoying Meno, he needs some way to win him back, so that Meno will not settle on the thought that his difficulties are just Socrates' fault. Aptly, then, once Meno compares Socrates to a stingray and deploys Meno's paradox, Socrates shifts out of his refutative mode - he quits critiquing what Meno says. Socrates could continue, since the argument in Meno's paradox is easily refutable. ${ }^{12}$ But when a student has clearly been refuted and denies that they have been, it is unwise to pile on more refutation.

The smarter choice is to remove the incentive that leads to wishful thinking - and to self-deception, if the classic theories of self-deception are correct. On all the classic theories, what determines whether a person will deceive themselves into holding some belief or other is simply whether there is enough inducement for them to do so - whether, at some level, they think they will gain more by holding the belief erroneously than by forming the opposite belief. ${ }^{13}$ Take Meno, for example. If he even sees the evidence that he has been refuted, he will deceive himself into believing he has not been, as long as he thinks the costs of believing otherwise would be too high. He is likely to think this, before the discussion in the Digressive Phase, since at that point it will seem to him that, if he accepts the idea that he lacks the knowledge he thought he had, then what he has acquired so far from Gorgias and others is useless, such that Meno no longer gets to do what he wants most, which is to wow people with flashy and novel spiels that make him seem like an expert. But if he believes that he still will be able to do this even if he accepts that he has been refuted, he will not deceive himself about whether he has been.

And in the Digressive Phase, Socrates gives him reason to think he will still be able. By the end of the digression, Meno has a colorful theory to offer people, the theory of recollection, which is exotic enough to come from mysterious priests and priestesses and to involve the idea of reincarnation, and which Gorgias' other protégés in Meno's 
Thessaly will not have heard of, so that Meno will not be upstaged if he uses it. Even better, Socrates has provided, as proof of the theory, a lively demonstration which Meno can easily replicate with some other slave-boy. And the upshot of the theory of recollection is the value of inquiry, refutation, and the befuddlement that often comes with them, so that once Meno accepts the theory, the idea that he has been refuted will be much easier to swallow.

I say 'once Meno accepts the theory' since he is almost bound to, as soon as he decides that it and the slave-boy demonstration have audience appeal. What is convincing to Meno is simply what he thinks will impress other people. (Consider, for example, how he reacts to Socrates' definition of shape. When Socrates first states his definition straightforwardly but plainly, Meno rejects it; yet Meno is convinced when Socrates then says roughly the same thing in a grand way; 75b-76d.) So, incidentally, offering Meno the theory of recollection not only offsets the third danger: it also provides an extra way of guarding against the first danger, so that the bases are doubly covered. It does so because it gives Meno compelling reason to think inquiry is manageable and, in turn, worth the effort - not reason that should be compelling, perhaps, but reason that will be compelling to Meno, given his predilections.

\section{Explaining the value of inquiry}

Plainly enough, Socrates plays to those predilections in providing the theory and the demonstration. Arguably, he does not even believe the theory, at least the version of it that he offers Meno. ${ }^{14} \mathrm{~A}$ while after laying it out, he distances himself from it somewhat (86b6-7), as if it is just packaging, a device for winning Meno over; and beneath it is a less glitzy but levelheaded account that he presents later (at 97c-98a, toward the end of the Constructive Phase), an account of the value of knowledge and, by implication, the value of inquiry. Regardless, what he does in propounding the theory of recollection is offer an account that is suited to his interlocutor. For Socratic teachers to emulate him nowadays would be for them to offer an account that is suited to theirs. And typically, the account they presented would not need to be eccentric. For instance, it could be one that reflects the tame but levelheaded account that Socrates provides in the Constructive Phase. Here is an example of an account of that sort - an example of what Socratic teachers could tell students who doubted that inquiry was worth the investment or that being refuted is a good way to learn. ${ }^{15}$

Consider, first, some advantages that being refuted has over certain other means of learning - for example, rote memorization. Imagine, say, that a group of students simply memorizes a series of statements a teacher makes. This probably will not do much good, since after memorizing these statements, the students will be able to recite them, but they might not understand what the statements mean, and they might not know whether they are true. Suppose, then, that the students memorize more than just the statements; suppose that, in making each statement, the teacher explains it and gives an argument for it, and the students memorize not only the statements but also the explanations and all the arguments. Furthermore, suppose that, in class, the students understand everything the teacher says, they each think about the arguments carefully, and in the end they find them convincing. Will the students then have learned enough? To be sure, they will be better 
equipped than in the previous case, but there still are valuable skills they might lack. For example, they might be unable to formulate good arguments of their own. Plus, they might be unable to answer objections even to the arguments the teacher has given them. (After class one day, for example, one of them might present some of the arguments to a friend who raises questions that leave the student at a loss.) And though the teacher, in that case, might acquaint students with various objections and replies, the teacher will never have enough time to show them all the objections one can raise: there will always be a chance that, even long after the semester is over, the students will come across objections which are new to them and which seem to nullify the arguments they used to find convincing.

Of course, there will always be a chance of this no matter what; on the one hand, it often takes luck in order to think of good arguments, and on the other hand, all of us inevitably run the risk that our arguments will fall apart sometime. But there are ways a teacher can help us better our chances that they won't, by cultivating our ability to reply to new objections and devise arguments that are strong enough to withstand them in the first place. To see how, consider an analogy.

A friend of mine in his sixties started using a computer for the first time about a year ago and has struggled even with the most basic functions. I write for him detailed instructions for printing a document, for example ('First click option $X$, then select command $Y$ ' - and so forth), and everything works fine as long his computer acts as expected. But if he ever has to deviate from my instructions and improvise, he is lost. For example, if his printer defaults to double-sided printing and my instructions don't tell him how to change the default, he has no idea what to do.

Contrast him with another friend of mine, who is in her twenties and works on the tech staff at my university. Whatever software problem arises, she is able to solve it; but she has never taken a course in computer science. In her formative years, she simply spent hours experimenting with computers.

Why, beyond the obvious, is she so adept and he so at a loss? Socrates uses a helpful metaphor when he speaks of problem-solving in terms of navigation. In a famous exchange in the Meno, for example, he asks whether one needs knowledge rather than just true belief in order to find one's way to Larissa (97a-b), and in Plato's Republic he says that people who have only true belief instead of knowledge are no different from 'blind people who happen to travel the right road' (506c8). Unlike some of Socrates' other metaphors, this one fits. Imagine giving directions to someone who is blind - blind not from birth, let's suppose, but just because they are temporarily blindfolded. You might tell the person: 'Take ten steps forward, then turn left, then take eight steps' - and so forth. This is basically what it is to give directions to a tourist who does not have a map and is unfamiliar with a city they are visiting for the first time. It is also, in effect, what I do in giving computer instructions to my befuddled friend. And it is effectively what a teacher would do in presenting arguments to students who simply thought them over and then memorized them after accepting them. Once they had memorized them, they would have a procedure to follow ('Assert premise $X$, then premise $Y$ ' - and so on), just as the blind person, the tourist, and my friend do. But like the blind person, the tourist, and my friend, they might be at an impasse once they had to improvise - or, once they had to divert from the path they were given to follow. What they would need is familiarity with 
the terrain that surrounds the path, so that they knew which areas around it were obstructed, so to speak, and which were not.

The way they would gain that familiarity is through experimentation - trial and error - just as my tech-expert friend has benefited from it; experimenting with computers, the way she has, is akin to exploring the terrain around the path that instructions give you. But there is a significant difference between experimenting with computers and experimenting within inquiry. With computers, oftentimes, the results of your experimentation are clear right away: you can readily see whether a program has worked or failed. In inquiring, by contrast, you may step in a hole without realizing it: it may look as if your argument is sound, when in fact there are devastating objections to be raised that simply have not occurred to you. Moreover, when you are new to inquiry it often is too difficult to anticipate strong objections. Typically, when you develop the ability to anticipate them, you do so only over time, when someone has raised good objections over and over - when repeatedly you have crafted arguments of your own, put your full thought and effort into them, and then, through other people's criticism, discovered what you overlooked. That is why it is crucial for students to make attempts at forming arguments, and it is part of why it can be vital for teachers to raise objections, even devastating objections, to the arguments that students offer.

A teacher could explain all of this, in these words or in simplified form, to achieve the same end that Socrates achieves in presenting Meno with the theory of recollection. This account is basically correct, I think, and it is likely to be appealing even to many students in school. Many want to learn, yet they dislike the tedium of memorization and recapitulation, for example, and are eager to hear that some livelier alternative is better for them, much as, say, when food is tasty, we want to believe it is healthy. And accepting this account would position students to take refutations seriously. It would give them reason to think that, although objections can be tiresome, there is a lot to gain from them.

\section{Socrates' directiveness in the Digressive Phase and Constructive Phase}

In the Digressive Phase of the Meno, Socrates simply hands Meno the theory of recollection; it does not emerge from Meno's own thoughts. Then in the Constructive Phase, Socrates feeds Meno additional views, which Meno accepts. Though Socrates asks questions there, he tends to ask only leading questions. (And at times, in fact, he does not even pose questions; he just states a position; see, for example, 97d-98a.) How can it be appropriate for him to do this? In being so directive, how can he keep from stifling Meno's thinking?

My answer will build on the account I just sketched and will reflect a line that many scholars have taken lately. Many have said that, in feeding views or arguments to his interlocutors, Socrates provides them not with final answers but with starting points for inquiry. There are several ways he may do this. At times, for example, when he talks with people who are enthusiastic about inquiry but only novices at it, he may point them toward new issues to inquire about, issues that are meatier than the ones they have already explored. He may do this by offering arguments whose conclusions "prefigure the way that "hypotheses" 
function in modern science', as one commentator puts it, 'namely as the basis for research programmes which are designed to test, and if possible to disprove, the hypotheses through systematic enquiry'. ${ }^{16}$ At other times, with interlocutors who are new to inquiry and not yet invested in it, Socrates may present an argument that provokes them - for example, an argument which is counterintuitive enough that they will want to combat it - or he may entice them with an argument that is compelling but not quite adequate, so that they will try to improve on it. ${ }^{17}$ Sometimes he also may voice a view when his interlocutors are too ashamed to admit they hold it; ${ }^{18}$ or through leading questions (or even declarative statements), he may elicit his interlocutors' beliefs so that he then can cast doubt on them. One scholar, in fact (Peterson, 2011), has proposed that Socrates does the latter even in dialogues such as the Republic where he has relatively advanced interlocutors. On her interpretation, the Republic shows just the first part of a larger conversation between Socrates and his interlocutors - namely, the part where he simply elicits their views. If the discussion continues past the point where the Republic ends, Socrates will scrutinize those views once he has the chance. In the part of the conversation shown in the Republic, in other words, he hands his interlocutors a bulky argument just to set them up for a fall.

Even if that interpretation is incorrect about the Republic, something similar is clearly true about the Meno. In the Constructive Phase, especially, Socrates sets Meno up for a fall. As Socrates hands over argument after argument and Meno happily accepts them, Anytus grows angrier and angrier and more and more incredulous. At the end, Socrates leaves: he will not raise objections to the views Meno now has in hand. But Anytus will if he has the chance. And evidently, Socrates is counting on this. Once Meno is fully persuaded and Socrates is set to leave, he tells Meno on his way out: 'You convince your guest friend Anytus here of these very things of which you yourself have been convinced, in order that he may be more amenable' (100b7-c1).

In the Meno, of course, Socrates does not get Meno to formulate arguments of his own, and Meno probably does not think very thoroughly before accepting the arguments that Socrates hands him. But Socrates has to start somewhere. Most likely, Meno is not willing yet to craft arguments for himself: Socrates probably has to hand him arguments if he is to hold his attention. And although in the dialogue itself Meno is quick to accept the arguments Socrates gives him, he will have to think more seriously soon, once he talks with Anytus. Given how new to inquiry Meno is, he will be ill-equipped to answer Anytus' objections, even if they are weak; so although Meno has these arguments in his grip for now, he will have to struggle to hold onto them, and they will probably slip from his fingers before long. Plus, even if he goes on accepting them indefinitely, not all is lost, since one of the arguments, the one about the value of knowledge (97c-98a), directs Meno toward further inquiry.

Socrates, in short, has a workable strategy here. And obviously, it is easy enough for teachers today to imitate. At times, in fact, many of them probably do more or less the same thing already: hand a student an argument that looks appealing, only then to subject it to criticism, including criticism from other students.

\section{Why take the risks?}

So far I have argued that Socrates has sensible ways of minimizing the risks he faces in the Meno and that teachers today can use the same sorts of devices, but a remaining 
question is why the risks are ever worth taking. There is no guarantee that the strategies I have described will be successful, and there can be problems if they fail. So why not simply avoid the risks in every situation? How can it be legitimate for Socrates to take these risks or, more important, for a modern-day teacher to do so?

In response to that question, I will make two main claims. The first is that there are times when a teacher needs to refute students and be directive with them if the students are to end up with solid reasons for their beliefs. The second is that having solid reasons is important to every student, because it is important to everyone who holds beliefs. I have already indicated part of my rationale for the first claim. I will add just a bit more before moving to the second claim.

First, take refutation, for example. In some cases, it is valuable for a teacher to refute a student when, mistakenly, the student thinks they already know enough that they have no need of the teacher or, say, the student's classmates. The refutation need not be delivered roughly; ${ }^{19}$ the purpose of it need not be to humble the student; ${ }^{20}$ and the teacher need not assume that they know more than the student, on every issue or any. ${ }^{21}$ After earnest consideration, the teacher may simply make a responsible guess that they or the student's classmates have something to contribute to the student's learning, just as the student might have something to contribute to theirs; and refutation may simply be the best way to show the student why the teacher thinks this. Refuting a student can be a way of honoring the student's autonomy, in a Kantian sense. ${ }^{22}$ It can be a way of respectfully offering them reason to think that, despite appearances, other people have a contribution to make.

Refutation may have benefits also when a student has the wrong standards by which to judge the merits of ideas and, in turn, wants the wrong thing from the teacher, much as Meno wants the wrong thing from Socrates at first. At first, Meno is after splashy logoi rather than ones that are defensible, and he sees no value in seeking the latter. It is helpful for Socrates to show him during the Refutative Phase that sometimes splashy ideas look empty on examination.

Finally, it can be vital to offer refutations in order to model a proper use of them. Public exchanges on political issues have a shrill tone nowadays, much as they did in Socrates' Athens. As a result, many students in school, for example, now see reasoned discussion just as a means of jockeying for power or kudos, and they sometimes enter disagreement in the wrong spirit or even shy away from it, assuming that there cannot be productive debate that ends on friendly terms. It is good to change their minds.

In each of the three sorts of cases I just mentioned, the point is for students to end up with solid reasons for their beliefs. (For example, when a student thinks they don't need their classmates or the teacher, the point is for the student to hear what others say, in case the student might miss significant objections otherwise or the chance to subject their views to scrutiny.) As I put it, having solid reasons is important to every student, because it is important to everyone who holds beliefs. That is the second of my two main claims. Here, in brief, is the reason for it, which I borrow from certain political philosophers and argumentation theorists. ${ }^{23}$

Start with the following thought experiment. Suppose you could take a pill that would give you true beliefs. When someone asked you questions, you would give the correct answers, even if you had no knowledge to draw from. Someone could ask you how many Francophones live in Moncton, New Brunswick, and you would answer correctly, even 
though you had never been to Canada or read a census report. Similarly, when you were asked: 'Is abortion wrong in every circumstance?' your answer would be true. Suppose, however, that you would not be able to explain why it is true; though you would have true beliefs, you would have no reasons for them, or no decent reasons anyway.

Taking this pill might be a good idea, because of how good it is to have true beliefs. But if we had true beliefs without a way to explain them, we would miss out on something important to us. Though our beliefs would be correct, we would not understand why they are, and in that sense we would not be in possession of the truth or in command of our cognitive lives. Yet we want to be in command of them; and in fact, we don't just prefer to have good reasons for our beliefs. In our view, having them is integral to believing. I will elaborate on this only a bit, using another analogy.

All ordinary human beings have an informal theory of human psychology. (We have, in other words, what philosophers of mind call folk psychology.) We might refine our informal theory somewhat once we have studied formal psychological theories, but even then the informal theory stays largely the same, because the principles it consists of are as basic as these:

- People who get injured generally feel pain.

- People who are in pain often get angry.

- People who are angry are generally impatient. ${ }^{24}$

Analogous to our informal theory of psychology is an informal theory about epistemology which we all share and which consists of the following principles:

- To hold a belief is to believe something. In other words, every belief has content.

- To believe something is to think it is true.

- To think it is true is generally to take oneself to have adequate reasons for this belief (or, as philosophers would say, reasons that warrant the belief).

We might refine these principles somewhat once we study philosophy, but even then they do not change much, since they are fundamental to the way we think. Even the third principle is; it is less contentious than it might look at first. It allows, for example, that some people have bad reasons or even no reasons for their beliefs. ${ }^{25}$ All it means is that, in holding a belief, we generally take ourselves to have adequate reasons for it, where a reason is simply whatever seems to the believer to indicate that the belief is true.

Given that we subscribe to this folk epistemology, we all hold ourselves to a certain norm: generally, we expect ourselves to have adequate reasons for our beliefs. And students are no different. Thus, to aid their deliberation is not to impose on them a set of values that is arbitrary or alien to them, for example. It is simply to answer to a standard they impose on themselves.

\section{Conclusion}

Despite how revered Socrates is among many educators nowadays, he can seem in the end to be a poor model for them, particularly because of how often he relies on 
refutations and leading questions. Refuting people can turn them away from inquiry instead of drawing them in, and being too directive with them can squelch independent thought. In revisiting the Meno, however, I have argued that there is reason to give Socrates a second look. To be sure, when he refutes Meno, there is a risk that Meno will forego inquiry if, say, he decides it is too difficult or stays convinced that he already has knowledge; and when Socrates later hands him arguments, Socrates runs the risk that Meno will never come to think for himself. But Socrates has sensible ways of minimizing these risks - such as by explaining the value of inquiry with a theory that Meno will want to accept, and by positioning Meno to have to defend the arguments he is given and teachers today can use the same sorts of strategies when they face comparable risks. Moreover, there are times when the risks are worth taking if they cannot be eliminated altogether. Socrates still has flaws, of course - significant ones, no doubt - and surely, modern-day educators should not imitate him in every respect. But if I am right, there is more to him than there can often seem to be.

\section{Acknowledgements}

Thanks to Tomas Bogardus, Michael Gose, Jenifer Hummer, Don Marshall, and the anonymous reviewers for Theory and Research in Education for their comments on (parts of) previous drafts.

\section{Declaration of conflicting interests}

The author(s) declared no potential conflicts of interest with respect to the research, authorship, and/or publication of this article.

\section{Funding}

The author(s) received no financial support for the research, authorship and/or publication of this article.

\section{Notes}

1. On the danger of just discouraging or annoying one's interlocutor, see, for example, Blondell (2002: 125-127), Clay (2000: 179-184), Pekarsky (1994: 125-126). For discussion of how Socrates shames people and what his motives may be, see, for example, Brickhouse and Smith (2015: 22ff.), Tarnopolsky (2010: esp. 86-87), Moss (2005).

2. See, for example, Noddings (2016: 5), Fullam (2015: 61, 68), Rancière (1991: 29, 59).

3. It seems this way to Jonas (2015: 40).

4. See 270b1-272b6, 273d8-e4, 277b8-c3. Herein all references to Plato's works are to the Greek text in Burnet's edition in the Oxford Classical Texts series, and all translations are based on the ones in Cooper (1997). Hereafter all references to Socrates will be to the character in Plato's dialogues, as opposed to the historical figure, for example, or the character in Xenophon's works. I will bracket the question of whether the Socrates in Plato's Phaedrus, for example, is the same character as, say, the Socrates in Plato's Apology.

5. Plato might not endorse Socrates' actions in the Meno. On Xenophon's account (Anabasis 2.6.21-27), the historical Meno displayed abject vice especially toward the end of his life; quite likely, Plato means for us to assume that his fictive Meno will end up doing the same and, thus, that Socrates' attempt to lead him to virtue will turn out to be unsuccessful. One possibility, accordingly, is that Plato presents Socrates' strategy in the Meno as a lesson in what to avoid. This is not the only possibility, though. Another, for example, is that Plato has 
Socrates fail, both in the Meno and elsewhere, just to keep him from 'functioning as a model for unreflective imitation' (Blondell, 2002: 103, emphasis added; see 84-112; and see, for example, Scott, 2000: ch. 5, for a sample of other possible reasons Plato has Socrates fail). Plato may think that, with Meno, at least, Socrates does the best one can do - that is, that leading people to virtue simply is difficult. Regardless, maybe this is what we should think.

6. As Mintz (2006: 481) notes, Socrates' discussion of geometry at $82 \mathrm{~b}-85 \mathrm{~b}$ is an anomaly in Plato's dialogues. Socrates' topics of conversation are almost always philosophical issues.

7. We have to conclude that this claim is refuted even if we think justification is relatively cheap, such as if we accept epistemic conservatism, as epistemologists call it. Consider, for example, McCain's (2008) version of it. McCain argues that if someone holds a belief that is not incoherent (for example, the belief that they can defend a certain claim adequately), the person is thereby justified in retaining that belief, all things being equal; but McCain allows that the person is no longer justified once the belief has been defeated for them, and he says that one way it can be defeated for them is if they end up with better reasons for denying the belief than for affirming it (p. 186). Meno surely meets this condition by the end of the Refutative Phase.

8. As Pekarsky (1994: 127-28) notes, the student also might infer not that inquiry is too difficult but that it is empty: all reasoning serves only to measure how clever a reasoner is, and it does nothing to indicate what is true. In response, though, the teacher can point out simply that that inference is itself an instance of reasoning and, thus, is self-refuting. Similarly, if the student decides we should give up on inquiry because there is no truth to be found, the teacher can point out the problem with thinking it is true that there is no truth, whereupon the student will be refuted again and the teacher will face the three dangers listed in the main text here.

9. Besides self-deception or wishful thinking, a Freudian subconscious, for example, might lead the student to deny that they have been refuted. If it does, however, there probably is little a teacher can do to help, short of leading the student through psychoanalysis.

10. These are commonplaces among scholars (see, for example, Klein, 1965: 44-45, 71-73; Scott, 2005: 12-13, 60-62; Weiss, 2001: 18-20, 78).

11. According to Aristotle, the historical Gorgias did not provide a systematic training in rhetoric but simply handed his pupils speeches to memorize (Sophistical Refutations 183b36-184a8).

12. The argument trades on an equivocation that is easy to identify. In the following rendition of the argument, the equivocation is on the term 'know':

1. For all $X$, either you know $X$, or you do not.

2. You cannot seek $X$ if you know it already.

3. Neither can you seek $X$ if you do not know it, since you then will not know what to look for.

4. Thus, for any $X$, inquiry into $X$ is futile.

In premise 2 'know' must mean 'know everything about', whereas in premise 3 'know' must mean 'know anything about'. The argument is unsound if we hold the meaning of 'know' stable, since in that case premise 2 or 3 is false; and the argument is unsound if we shift the meaning of 'know', since premise 1 then is false. I borrow some of my wording here from Shields (2012: 64-65), who offers a fuller and especially pithy explanation.

13. The classic theories are versions of so-called intentionalism and deflationism. The chief issue between the two is whether self-deception is intentional - or, whether people who engage in self-deception mislead themselves knowingly, in roughly the way one person might deceive another person. Whereas intentionalists such as Davidson (2004 [1986]) say the answer is 
'yes', deflationists such as Mele (for example, 2001) think the answer is 'no'. But even Mele says that self-deception is always motivated by a desire - self-deception has the function of sating the desire (for example, the desire to dazzle people the way Meno wants to) - such that, without the requisite desire and, in turn, an incentive, there will be no self-deception. Some recent theorists, such as Smith (2014), hold that self-deception, ultimately, is due not to a desire or incentive but to sub-personal mechanisms instilled in us most likely by natural selection: for the good of the species, perhaps, we simply are hard-wired to deceive ourselves in certain cases. As Lynch (2017: 784-785) notes, one problem with theories such as Smith's is that they do not accommodate the powerful intuition that a person's self-deception is something they are responsible for.

14. Weiss (2001) argues that he does not. She holds that Socrates means to deceive Meno with the theory of recollection because Socrates sees that Meno would reject inquiry if he realized how inconclusive it is.

15. For a fuller version of the explanation in the next five paragraphs, see Marshall and Clark (2010: 274-281).

16. Gill $(2000,142)$. There are similar claims in Cotton (2014: 25-27) and Kamtekar (2012: 269-270), for example. References here and in the next two notes could easily be proliferated.

17. Rider (2011, 2012), for example, says that Socrates does the former in Plato's Lysis and the latter in Plato's Euthydemus.

18. Shaw (2015: ch. 3), for example, thinks Socrates does this in Plato's Protagoras, and Kahn (1983) is one who sees something similar in Plato's Gorgias.

19. Rud (1997: 8-9) and Thomas (1985: 222) seem to value a certain amount of roughness.

20. Pekarsky (1994) wants to correct 'intellectual smugness' (p. 121), in his phrase. Carr (2018) sees a need to shed 'pride and vanity' (p. 12), as he puts it. Arguably, Socrates, too, hopes to instill humility; see, for example, 41e1-42a2 in Plato's Apology and 201b-d in his Theaetetus.

21. Rancière (1991) worries that Socrates assumes he knows more or is smarter than his interlocutors. On this concern, see, for example, Fullam (2015: 54ff), Kohan (2011: 351), Lewis (2012: 123-125).

22. Roughly, a person's autonomy is their capacity to script their own lives in accordance with reasons and motives that are genuinely their own as opposed to being foisted on them. Kant (1785) believes we must respect other people's autonomy and that it thus is wrong to treat them as means. For him, a main difference between treating them as means and treating them as ends has to do with how one tries to convince them to act in one way or another. I treat them as ends when I offer them reasons for acting this way, reasons that I think are strong, and then simply leave it to them to judge the merits of those reasons. I treat them as means when I go farther than this and try to manipulate them such as by tricking or deceiving them, influencing them in ways they would not accept if they were aware of what I am doing. So, for example, to treat others as means is to lie to them, intimidate them, embarrass them, or guilt them into one course of action or another, instead of simply presenting them with arguments that persuade me and letting them see whether these arguments persuade them, too.

23. See especially Misak (2004), Talisse (2009), and Van Eemeren and Grootendorst (2004). The thought experiment in the next paragraph is based on one in Aikin and Talisse (2014: 21).

24. I quote and slightly modify Hedman (2017: 141), which paraphrases Paul Churchland.

25. It also meshes with what epistemologists call externalism, because we want adequate reasons, and we want access to them, even if we don't need it in order for our beliefs to be justified (see Talisse, 2009: 98-99). Furthermore, the principle coheres with anti-evidentialism, since the point is not that we should not believe without sufficient evidence, but just that we are incapable of doing so self-consciously except in certain atypical cases (for example, cases of delusion or psychosis and perhaps certain cases of religious belief). 


\section{References}

Aikin SF and Talisse RB (2014) Why We Argue (And How We Should): A Guide to Political Disagreement. New York: Routledge.

Blondell R (2002) The Play of Character in Plato's Dialogues. Cambridge: Cambridge University Press.

Brickhouse TC and Smith ND (2015) Socrates on the emotions. Plato Journal 15: 9-28.

Carr D (2018) Ancient roads to knowledge: The Greek philosophical legacy. In: Harrison T and Walker DI (eds) The Theory and Practice of Virtue Education, pp. 7-18. New York: Routledge.

Clay D (2000) Platonic Questions: Dialogues with the Silent Philosopher. University Park, PA: Pennsylvania State University Press.

Cooper JM (ed) (1997) Plato: Complete Works. Indianapolis, IN: Hackett.

Cotton AK (2014) Platonic Dialogue and the Education of the Reader. Oxford: Oxford University Press.

Davidson D (2004 [1986]) Deception and division. In: Elster J (ed) The Multiple Self, pp. 79-92. Cambridge: Cambridge University Press (Reprinted in: Problems of Rationality, pp. 119212. Oxford: Clarendon Press).

Fullam J (2015) 'Listen then, or, rather, answer': Contemporary challenges to Socratic education. Educational Theory 56(1): 53-71.

Gill C (2000) Protreptic and dialectic in Plato's Euthydemus. In: Robinson TM and Brisson L (eds) Plato, 'Euthydemus', 'Lysis', 'Charmides': Proceedings of the V Symposium Platonicum, Selected Papers, pp. 133-143. Sankt Augustin: Academia Verlag.

Hedman A (2017) Consciousness from a Broad Perspective: A Philosophical and Interdisciplinary Introduction. Cham: Springer.

Jonas ME (2015) Education for epiphany: The case of Plato's Lysis. Educational Theory 65(1): $39-51$.

Kahn CH (1983) Drama and dialectic in Plato's Gorgias. Oxford Studies in Ancient Philosophy 1: $75-121$.

Kamtekar R (2012) Socrates and the psychology of virtue. Classical Philology 107(3): 256-270.

Kant I (1785) Grundlegung Zur Metaphysik Der Sitten. Riga: Johann Friedrich Hartknoch.

Klein J (1965) A Commentary on Plato's 'Meno'. Chicago, IL: University of Chicago Press.

Kohan WO (2011) Childhood, education and philosophy: Notes on deterritorialisation. Journal of Philosophy of Education 45(2): 339-357.

Lewis TE (2012) The Aesthetics of Education: Theatre, Curiosity, and Politics in the Work of Jacques Rancière and Paulo Freire. New York: Continuum.

Lynch K (2017) An agentive non-intentionalist theory of self-deception. Canadian Journal of Philosophy 47(6): 779-798.

McCain K (2008) The virtues of epistemic conservatism. Synthese 164(2): 185-200.

Marshall M and Clark AM (2010) Is clarity essential to good teaching? Teaching Philosophy 33(3): 271-289.

Mele AR (2001) Self-Deception Unmasked. Princeton, NJ: Princeton University Press.

Mintz A (2006) From grade school to law school: Socrates' legacy in education. In: Ahbel-Rappe $\mathrm{S}$ and Kamtekar R (eds) A Companion to Socrates, pp. 476-492. Malden, MA: WileyBlackwell.

Misak C (2004) Making disagreement matter: Pragmatism and deliberative democracy. Journal of Speculative Philosophy 18(1): 9-22.

Moss J (2005) Shame, pleasure, and the divided soul. Oxford Studies in Ancient Philosophy 29: 137-170.

Noddings N (2016) Philosophy of Education, 4th edn. New York: Routledge. 
Pekarsky D (1994) Socratic teaching: A critical assessment. Journal of Moral Education 23(2): $119-134$.

Peterson S (2011) Socrates and Philosophy in the Dialogues of Plato. Cambridge: Cambridge University Press.

Rancière J (1991) The Ignorant Schoolmaster: Five Lessons in Intellectual Emancipation (trans. K Ross). Stanford, CA: Stanford University Press.

Rider BA (2011) A Socratic seduction: Philosophical protreptic in Plato's Lysis. Apeiron 44(1): 40-66.

Rider BA (2012) Socrates' philosophical protreptic in Euthydemus 278c-282d. Archiv Für Geschichte Der Philosophie 94(2): 208-228.

Rud AG (1997) The use and abuse of Socrates in present day teaching. Education Policy Analysis Archives 5(20). Available at: http://epaa.asu.edu/ojs/article/viewFile/621/743

Scott D (2005) Plato's 'Meno'. Cambridge: Cambridge University Press.

Scott GA (2000) Plato's Socrates as Educator. Albany, NY: State University of New York Press.

Shaw JC (2015) Plato's Anti-Hedonism and the 'Protagoras'. Cambridge: Cambridge University Press.

Shields C (2012) Ancient Philosophy: A Contemporary Introduction, 2nd edn. New York: Routledge.

Smith DL (2014) Self-deception: A teleofunctional approach. Philosophia 42(1): 181-199.

Talisse RB (2009) Democracy and Moral Conflict. Cambridge: Cambridge University Press.

Tarnopolsky CH (2010) Prudes, Perverts, and Tyrants: Plato's 'Gorgias' and the Politics of Shame. Princeton, NJ: Princeton University Press.

Thomas DW (1985) About teaching and teachers: The torpedo's touch. Harvard Educational Review 55(2): 220-222.

Van Eemeren FH and Grootendorst R (2004) A Systematic Theory of Argumentation: The PragmaDialectical Approach. Cambridge: Cambridge University Press.

Weiss R (2001) Virtue in the Cave: Moral Inquiry in Plato's 'Meno'. Oxford: Oxford University Press.

\section{Author biography}

Mason Marshall is associate professor of Philosophy at Pepperdine University. His main area of research is ancient philosophy. 